\title{
The Effect of Achievement Motivation on Students' Learning Outcomes in Writing English Descriptive Paragraph through Individual and Group Work Method
}

\author{
Sriati Usman \\ Universitas Tadulako, English Education, \\ Teaching Training and Education Faculty \\ Palu, Indonesia \\ sriati.endro@gmail.com
}

\begin{abstract}
Achievement motivation is a hard intention followed by a hard effort which owned by the students in order to reach high learning outcomes. This research at aims to find out the difference of students' learning outcomes as an effect of achievement motivation in writing English descriptive paragraph through individual and group work method. It was a quasiexperimental research nonequivalent control group design, implemented into five different parallel classes. The technique of selecting sample was purposive sampling in which $\mathbf{A}$ as control class and $B$ as experimental one with 86 total students, and 78 students were accepted as a subject survey. Data of students learning outcomes collected through pretest and posttest. While data on students' achievement motivation used questionnaire. The pretest data were taken before treatment, used to determine students' variance, whereas posttest data was taken after treatment entirely finished to find out students' learning outcomes differences. Data analysis using variance factorial $2 \times 2$ (two way ANOVA). The hypothesis testing was conducted with $5 \%$ of significance level. The result of data analysis showed that the pvalue of $t$-counted is 0.000 lower than $0.05(<0.05)$. It could be concluded that there was a significant difference in learning outcomes between the students with high achievement motivation and the students with low achievement motivation in writing English descriptive paragraph through individual and group work method.
\end{abstract}

Keywords-High, Low, Achievement Motivation, Learning Outcomes.

\section{INTRODUCTION}

Achievement motivation is a hard intention followed by a hard effort which owned by the students in order to reach high learning outcomes. There are two kinds of achievement motivation. They are low and high achievement motivation. Students who have a high achievement motivation tend to do little tasks but it has a high challenge, while students who have low achievement motivation, they tend to avoid complicated and challenging tasks. Maheswari and Aruna [1] state that achievement motivation is a process of fighting to achieve an ideal by applying the highest standard of excellence in all activities. while [2] states that achievement motivation is one of the important psychological factors that play an important role to determine future education and occupation. It is most similar to [3]. They define that achievement motivation is a hard intention to do tasks based on the highest standard (excellence) or an intention to get a success in a competitive atmosphere. It is also an encouragement from the inside of a person to overcome any challenges and obstacles in the process to reach a goal and as an expectation to get a satisfaction in taking control of challenging and a difficult performance. If his or her ideal is achieved, he or she will praise to his or herself, if it is not, he or she will be disappointed. In other words, achievement motivation is an impulse arising from a person to reach the highest achievement.

The previous statements are sharpened by [4] that it is not only achievement motivation can increase student's learning outcomes, but it can be affected by many factors. They are:1) physiological factor, 2) physiology factor, 3) physical and psychological maturity factors, 4) social factor, 5) culture factor, 6) physical environmental factors, and 7) environmental and safety factors.

A related research to the effect of achievement motivation toward students' learning outcomes had been conducted by many experts. One of them is [4] states that there is a positive correlation between achievement motivation and the role of parents in students' learning outcomes. It means that the higher achievement motivation and the role of parents, the learning achievement tend to be higher too. Furthermore, [5] conduct a research on achievement motivation level in students of medical sciences and its influential factors. They find that there are six factors with the most effect on academic motivation are 1) family attitudes, 2) getting good jobs in future, 3) respect for themselves, 4) the ability to learn, 5) believing their role in the victory, 6) defeat and the tendency toward optimism about themselves.

By comparing factor by factor showed that Dentistry and Hospital Management had a significant decrease in motivation score by an increase in educational years. It shows that achievement motivation level of students was higher than average and did not decrease during the educational year. Other similar research also is about academic ability and achievement motivation as moderator variables was conducted by [6]. His findings show 1) there was a significant interaction between academic ability and achievement motivation toward learning outcomes, 2) there is a significant difference between instructional strategy, academic ability, and achievement motivation toward students' learning outcomes.

With reference to the above statements, it can be concluded that students' success to reach the highest achievement is 
affected by the level of motivation and by pay attention to instructional principles. One of the instructional principles is achievement motivation that can affect students' learning outcomes as a form of success that will be achieved by each student. It is, of course, the success is obtained from a hard will and effort.

In line with the statements, the objective of this research is to find out a significant difference in students' learning outcomes as an effect of achievement motivation in writing English descriptive paragraph through individual and group work method.

\section{METHOD}

The method of this research is a quantitative, quasiexperimental research that is modified from a true experimental research. It is a study that tested the hypothesis of a causal relationship between variables[7]. The design of this research is factorial design. It is a variation between groups design consisting of two or more treatment variables to test independent variable and simultaneous effect on learning outcomes [8]. In other words, the factorial design is defined as research structures that involve independent, moderator, and dependent variables in which the analysis standard of its variant is equal to the number of independent and moderator variables.

Other experts state that this study can be also called as a factorial design, nonequivalent control group design version, particularly, 2x2 or two-way factorial design [7]

\section{A. Subject of Research}

The subject of this research is the students of the third semester of English education study program, language and art education of teacher training and education faculty, Universitas Tadulako in 2013/2014 academic year consisting of five classes. Each class has 40 students or the total number of the students are 200 (two hundred). However, only two classes were selected purposively to be the sample. They are B class as an experimental group and A class as control one. During the teaching and learning process only 39 students of class A and $B$ who were active until the end of the semester. So, the student's total number of the two classes, both experimental and control group were 78 students.

\section{B. Instruments of Research}

The instruments used in this research were tests and questionnaire. The test consist of two, they were pretest and posttest. The pretest was given to both experimental and control group before treatment, and posttest was given to the two groups after conducting treatment. While questionnaire used to collect data of low and high achievement motivation, and their effect toward students' learning outcomes. Questionnaire of achievement motivation used to collect data was developed by [9]. It was deal with 14 questions that must be answered by the students of experimental and control group. Moreover, it was used to find out information on a problem simultaneously and concurrently [10]. Furthermore, [11] states that questionnaire as an instrument to find out information through a number of written questions and statements of factual data, or an opinion that closed related to respondents.

\section{Validity and Reliability of Instrument}

The questionnaire which provided for respondents must have a high validity and reliability. It can be proved through the used of test to measure what actually must be measured [12]. To find out the validity of 14 items of achievement motivation questionnaire, it was used Product Moment Correlation formula which developed by Pearson. Instrument validity test can be stated valid if the value of significant is lower than $5 \%$ or alpha coefficients $(\alpha<0.05)$. The result of achievement motivation instrument validity test of the experimental group was the value of significant was lower than $5 \%$ or alpha coefficients $(\alpha<0.05)$. So, the 14 th items of achievement motivation questionnaire were valid. Otherwise, instrument reliability test was stated reliable, if the value of alpha coefficients was greater than 0.60. The result of achievement motivation instrument reliability test of the experimental group was alpha coefficients 0.865 or it was between $0.70-0.90$. It meant a number of alpha coefficients were greater than 0.60 . It showed that the achievement motivation instrument test that consists of 14 items had a high reliability.

Moreover, the result of achievement motivation instrument test of the control group was the value of significant is lower too than $5 \%$ or alpha coefficients $(\alpha<0.05)$. So, the 14 th items of achievement motivation questionnaire were stated valid too and the result of achievement motivation instrument reliability test was alpha coefficients 0.899 or the scores between $0.70-$ 0.90 . it meant that a number of alpha coefficients were greater than 0.60. It showed that the instrument of achievement motivation that consists of 14 items which applied at control group had a high reliability.

\section{Analysis of Data}

Data were gathered through tests analyzed statistically by applying the analysis of variance or two-way factorial $(2 \times 2)$. The testing null hypothesis was conducted at $5 \%$ of significant level or $\alpha=0.05$. To find out the significant difference in low and high achievement motivation of students' learning outcome, it was applied:

There is a significant difference between both group of students' learning outcome if the value of significant ANOVA test was lower than $5 \%$ or Sig. $<0.05$.

There is no significant difference between both group of students' learning outcome if the value of significant ANOVA test was greater than $5 \%$ or Sig. $>0.05$.

\section{RESULT AND DISCUSSION}

\section{A. Achievement Motivation Variable}

Achievement motivation variable was measured by standardized achievement motivation questionnaire, where the test results consist of 14 valid and reliable question items that based on the validity and reliability test result using Person's Correlation Product Moment or Alpha Cronbach. Based on the test result validity of achievement motivation questionnaire on the experimental class, it is concluded valid because of the sig. $<0.05(\alpha 5 \%)$.

Achievement motivation questionnaire on the experimental class also had high reliability because Cronbach's alpha 0.865 is between $0.70-0.90$, while the test result validity on the control class had the same score which was, 0.05 ( $\alpha$ 5\%) meant 
all items used are valid, and also had high level of reliability that is shown by Cronbach's alpha 0.899 between 0.70-0.90.

The following table describes the results of achievement motivation variable measurements on each observed class.

TABLE I. DESCRIPTION OF ACHIEVEMENT MOTIVATION VARIABLE

\begin{tabular}{|l|c|c|c|}
\hline & $\begin{array}{l}\text { Low } \\
\text { Motivation }\end{array}$ & $\begin{array}{l}\text { High } \\
\text { Motivation }\end{array}$ & \\
\hline Class & $\mathrm{F}$ & $\mathrm{F}$ & Total \\
\hline Group Work & 19 & 20 & 39 \\
\hline $\begin{array}{l}\text { Individual } \\
\text { Work }\end{array}$ & 20 & 19 & 39 \\
\hline Total & 39 & 39 & 78 \\
\hline
\end{tabular}

As illustrated in Table I, the class of group work has 19 learners with low achievement motivation and 20 students with high achievement motivation, while there are 20 students with low motivation and 19 students with high achievement motivation in individual work class.

The following table presents the difference of post-test data between students with high and low achievement motivation.

TABLE II. POSTTEST DifFERENCES BETWEEN STUDENTS WITH High AND LOW ACHIEVEMENT MOTIVATION

\begin{tabular}{|l|l|l|l|l|l|l|}
\hline & $\begin{array}{c}\text { Achieveme } \\
\text { nt } \\
\text { Motivation }\end{array}$ & N & Means & SD & $\begin{array}{c}\text { T-test } \\
\text { Value }\end{array}$ & $\begin{array}{c}\text { Sig.(2- } \\
\text { tailed) }\end{array}$ \\
\hline $\begin{array}{l}\text { Post- } \\
\text { Test }\end{array}$ & Low & 39 & 87.79 & 5.859 & -9.818 & 0.000 \\
\hline
\end{tabular}

Table II reports the learners' posttest mean scores with low achievement motivation are 87.79 and high achievement motivation is 89.05. Based on P-value $0.000(<0.05)$, it is concluded that there is a significant difference between learners' posttest mean scores with low and high achievement motivation. The learners with high achievement motivation have higher posttest score than students with low achievement motivation.

\section{B. The Difference of Motivation Level Effect toward Learning Outcomes}

The hypothesis is being tested in this research is the effect of achievement motivation toward students' learning outcomes that in detail explained as follows

$\mathrm{H}_{\mathrm{o}}$ : There is no significant difference in learning outcomes of writing English descriptive paragraph between students with high achievement motivation and students with low achievement motivation.

$\mathrm{H}_{1}$ :There is a significant difference in learning outcomes of writing English descriptive paragraph between students with high achievement motivation and students with low achievement motivation.

This research classified motivation into two groups; low and high. The number of students with high achievement motivation is equal to the number of students with the low motivation that is 39 students.

Based on statistics, F-value 0.795, with $\alpha 0.005<0.0$, then, it can be interpreted that there is a significant learning outcomes difference between students group with low and high achievement motivation in learning English descriptive paragraph writing. The interpretation is that the students with high and low achievement motivation result in a difference in learning outcomes in writing English descriptive paragraph.

Based on the data result, the second null hypothesis that stated there is no significant difference between students with high achievement motivation and students with low achievement motivation was rejected and $\mathrm{H}_{1}$ was accepted.

\section{The Overview of Research Findings}

Based on the general description of research result and hypothesis testing result, then a summary of the research result can be described as follows: there is a significant difference between students with low achievement motivation and students with high achievement motivation on learning outcomes of writing English descriptive paragraph, with $\mathrm{F}$ value 0.795 and $\alpha=0.005<0.05$. It can be interpreted that the difference between high and low achievement motivation affects learning outcomes achievement.

This research successfully presents that achievement motivation has an effect on learning outcomes and quite significantly distinguish between students with high achievement motivation have high learning outcomes and students with low achievement motivation also have low learning outcomes. In other words, the data shows that there is a significant difference between a group of students with high and low achievement motivation. Students with high achievement motivation's means score are 89.05 and students with low achievement motivation is 87.79 , with $\mathrm{F}$ value 0.795 , sig $0.05<0.05$, shows a significant difference between two groups.

This condition shows that students with high achievement motivation are directly proportional to high learning outcomes and vice versa. Several possible causes are; (1) the influence of either group work or individual work learning methods, which means although using different learning methods, it is possible for the students to obtain high learning outcomes, if they have high achievement motivation and vice versa, (2) students with high achievement motivation are disciplined, diligent in doing assignments both inside and outside classroom, in other words, they are encouraged to do anything that was instructed happily without any fear and force because of pressure from their parents.

These findings are acceptable since many previous studies have similar results, as [4] states that there is a positive correlation between achievement motivation, parents' role, and learning achievements, where the higher motivation and parents' role are, the higher learning achievement will be. In line with [4], [1] also conducted a research on gender difference and achievement motivation. The finding of their research showed that there was a significant difference between gender of the respondent with regard to their achievement motivation, the $\mathrm{Z}$ value was higher than table value. So, research hypothesis was accepted and the null hypothesis is rejected.

Another similar research was done in the same field. Ref. [13] conduct a research on achievement motivation, study habits, and academic achievement. Their finding showed that there was a significant correlation between achievement motivation, study habits, and performance of students. Different from [6] states that there is no significant difference between students' achievement motivation and their learning outcomes. Even though means score showed that students with 
high motivation obtained a slightly higher score, but the difference was not significant.

Furthermore, [14] states that 3 research hypothesis was successfully answered by using Pearson Product Moment statistical correlation, with the findings that scale of achievement motivation score, the scale of attitude score and students' perception on learning method showed significant correlation toward chemistry learning outcomes. Another similar research is done by [15]. It is the influence of achievement motivation on academic achievement. His finding showed that there was a significant mean difference between different categories of achievement motivation. This study suggests that some factors which are related to achievement motivation are family background and school experiences.

The next similar study that was done by [16], also states that achievement motivation and self-concept have a significant relationship with learning outcomes. The significant difference was found in female students. The study suggested teachers use motivation strategy in engaging students in order to improve learning outcomes. Further, [17] have a research on the relationship among achievement motivation, place and family on 2nd-grade senior high school students. The finding states that there is no significant learning outcomes difference between students in downtown and suburbs. The study also reveals no significant difference in achievement motivation between students from joint family and the nuclear family.

Another research related to achievement motivation that was also done by [18] shows that commitment to the organization, work culture, and achievement motivation among lecturers, administration staffs and students at State University of Syarif Hidayatullah Jakarta is an important thing as an influence to reach a strategic position on universities international ranks.

Ref. [19] presents a research on the effects of achievement motivation, task difficulty and achievement difficulty toward psychology, behaviour, and personal effort. It stated that 16 participants with high achievement motivation showed better performance and had bigger decreased group frequency than 16 participants with low achievement motivation, especially in taking on a difficult task. This research result has a positive impact on achievement motivation, difficult task and difficult achievement on mobilization efforts. Last but not least, [20] conduct a research also on the effect of achievement motivation on high and low achievers. The result showed that achievement motivation had a significant effect on students' academic achievement. It also showed that there was a significant difference on the basis of gender.

Based on previous findings, it can be concluded that the success of the students to achieve high learning outcomes determined by motivation level regarding learning principles, which is one of them is achievement motivation that can influence learning outcomes as each student' success full manifestation. Certainly, success needs will and hard effort.

\section{CONCLUSIONS}

The conclusions of this research are learning outcomes of students group with high achievement motivation are significantly different from students with low achievement motivation, either on group work or individual work learning method. Means score data showed students with high achievement motivation had high learning outcomes, both of group work and individual group learning. Similarly, students with low achievement motivation had low learning outcomes, also both of group work and individual group learning. Therefore, before a teacher start his/her teching, he/she have to identify the level of achievement motivation of students by applying questionnaire in order to know which students have low achievement motivation and which one has high achievement motivation in order to ease the teacher to select the appropriate approach, method, technique, as well as media.

\section{REFERENCES}

[1] K. K. Maheswari and M. Aruna, "Gender difference and Achievement Motivation among Adolescent School Students," vol. 2, no. 1, pp. 149$152,2016$.

[2] K. Sabina, "The Role of Achievement Motivation in Educational Aspirations and Performance," Gen. Prof. Educ. 1, pp. 42-48, 2010.

[3] D. . Schunk, P. . Pintrich, and J. Meece, Motivation in Education: Theory, Research, and Applications, 4th ed. Pearson, 2012.

[4] S. Y. W. Iswanti, "Pengaruh Motivasi Berprestasi dan Peran Orangtua dengan Prestasi Belajar Siswa SMU Tarakanita I,” pp. 1-26, 2012.

[5] S. Kavousipour, A. Noorafshan, S. Pourahmad, and A. DehghaniNazhvani, "Achievement Motivation Level in Students of Shiraz University of Medical Sciences and Its Influential Factors.," J. Adv. Med. Educ. Prof., vol. 3, no. 1, pp. 26-32, 2015.

[6] Manesa, "Pengaruh Pembelajaran Kooperatif Jigsaw II, Motivasi Berprestasi, dan Kemampuan Akademik, terhadap Hasil Belajar Ilmu Pengetahuan Sosial Siswa Kelas V Sekolah Dasar," Program Pascasarjana UM, 2012.

[7] I. N. S. Degeng, Metodologi Penelitian. Malang: Pascasarjana Universitas Negeri Malang, 2000.

[8] J. W. Creswell, Research Design, 3rd ed. New York: Sage Publication Inc. Printed in the United States of America., 2009.

[9] I. N. S. Degeng, Karakteristik Belajar Mahasiswa Berpembelajaran Tinggi Negeri di Indonesia. Jakarta: PAU-UT Dirjen Dikti Depdibud, 1991.

[10] B. W. Tuckman, Conducting Educational Research, 4th ed. New York: Harcourt Brace College Publisher, 1999.

[11] A. Sutoyo, Pemahaman Individu: Observasi, Checklist, Interviu, Kuesioner, Sosiometri. Yogyakarta: Penerbit Pustaka Pelajar, 2012.

[12] P. M. Ngalim, Prinsip-Prinsip dan Teknik Evaluasi Pengajaran, 17th ed. Bandung: PT Remaja Rosdakarya Offset, 2012.

[13] A. Kumari and S.Chamundeswari"Parental involvement, self-regulated learning and academic achievement of students," no. February, pp. 153$160,2015$.

[14] GC Ilogu, "The Effect of Students' Achievement Motivation on their Cognitive Performance Behaviour," Int. J. Educ. Res., vol. 3, no. 1, pp. 105-113, 2007.

[15] S. A. Rather, "Influence of Parental Expectation on Academic Achievement of Secondary School Students," Int. Res. J. India, vol. II, no. III, p. 4, 2016.

[16] R. U. N. Awan, G. Noureen, and A. Naz, "A Study of Relationship between Achievement Motivation, Self Concept and Achievement in English and Mathematics at Secondary Level," A Int. Educ. Stud., vol. 4 , no. 3, pp. 72-79, 2011.

[17] K. Velmurugan and V. Balakrishnan, "Achievement Motivation of Higher Secondary Students in Relation to Locality and Type of Family," vol. 2, no. 5, pp. 7-12, 2013.

[18] M. Avicenna, Y. Adriani, and A. Mujib, "Organizational, Commitment, Work Culture, and Achievement Motivation," 2012.

[19] R. L. Capa, M. Audiffren, and S. Ragot, "The Effects of Achievement Motivation, Task Difficulty, and Goal Difficulty on Physiological, Behavioural, and Subjective Effort," Psychophysiology, vol. 45, no. 5, pp. 859-868, 2008.

[20] Rashmi and B. Prasad, "Effect of Achievement Motivation on High and Low Achievers of Secondary School Students : A Comparative Study," vol. 2 , no. 6, pp. 133-135, 2013. 